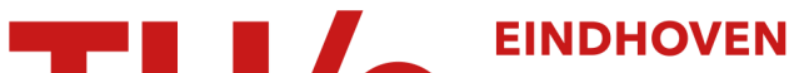 UNIVERSITY OF TECHNOLOGY
}

\section{Just-in-time patents and the development of standards}

\author{
Citation for published version (APA): \\ Kang, B., \& Bekkers, R. (2015). Just-in-time patents and the development of standards. Research Policy, \\ 44(10), 1948-1961. https://doi.org/10.1016/j.respol.2015.07.001
}

DOI:

10.1016/j.respol.2015.07.001

Document status and date:

Published: 01/12/2015

\section{Document Version:}

Accepted manuscript including changes made at the peer-review stage

\section{Please check the document version of this publication:}

- A submitted manuscript is the version of the article upon submission and before peer-review. There can be important differences between the submitted version and the official published version of record. People interested in the research are advised to contact the author for the final version of the publication, or visit the $\mathrm{DOI}$ to the publisher's website.

- The final author version and the galley proof are versions of the publication after peer review.

- The final published version features the final layout of the paper including the volume, issue and page numbers.

Link to publication

\section{General rights}

Copyright and moral rights for the publications made accessible in the public portal are retained by the authors and/or other copyright owners and it is a condition of accessing publications that users recognise and abide by the legal requirements associated with these rights.

- Users may download and print one copy of any publication from the public portal for the purpose of private study or research.

- You may not further distribute the material or use it for any profit-making activity or commercial gain

- You may freely distribute the URL identifying the publication in the public portal.

If the publication is distributed under the terms of Article 25fa of the Dutch Copyright Act, indicated by the "Taverne" license above, please follow below link for the End User Agreement:

www.tue.nl/taverne

Take down policy

If you believe that this document breaches copyright please contact us at:

openaccess@tue.nl

providing details and we will investigate your claim. 


\title{
Just-in-time patents and the development of standards
}

Byeongwoo Kang ${ }^{\mathrm{a}, \mathrm{b}}$, Rudi Bekkers ${ }^{\mathrm{c}, \mathrm{d}, \text { * }}$

${ }^{\mathrm{a}}$ The University of Tokyo, Japan
b Institute of Developing Economies (IDE-JETRO), Japan
${ }^{\mathrm{c}}$ Eindhoven Centre for Innovation Studies (ECIS), School of Innovation Sciences, Eindhoven University of
Technology, Eindhoven, The Netherlands
${ }^{\mathrm{d}}$ Dialogic Innovatie \& Interactie, Utrecht, The Netherlands
${ }^{*}$ Corresponding author: r.n.a.bekkers@tue.nl. Tel. +31 403475621.

This paper has been published as Byeongwoo Kang, Rudi Bekkers (2015). Just-in-time patents and the development of standards. Research Policy 44, 1948-1961.

\begin{abstract}
Modern technical standards often include large numbers of patented technologies that are required to implement those standards. These "standard-essential patents" are very valuable assets, and firms that do not own such patents are prepared to spend billions of dollars purchasing them. Whereas large numbers of standard-essential patents are often taken for granted, this study focuses on the process by which companies obtain such patents. Analyzing original data of a large standardization process, we demonstrate how many companies use a strategy we call "just-in-time patenting": They apply for patents of low technical merit just before a standardization meeting, and then send the patents' inventors to the meeting to negotiate this patented technology into the standard. Our findings have several implications for standard-setting organizations, patent offices, and policymakers, as the inclusion of justin-time patents may reduce competition and market entry, increase prices, and unnecessarily complicate the technological content of standards.
\end{abstract}

Keywords: patents, standards, essential patents, SEPs, strategic behavior, W-CDMA, LTE

\section{Introduction}

In recent years, there has been an explosion of lawsuits over patents in the context of technical standards for smartphones and mobile phones, tablets, personal computers, video consoles, etc. These cases involve many well-known companies like Apple, Samsung, Motorola, Nokia, Google, HTC, Microsoft, Kodak, and BlackBerry. This situation might be further exacerbated by the increasing role of companies that do not manufacture or use their patented technologies, but instead focus on licensing. Such companies, which are also known 
as non-practicing entities (NPEs), are especially keen on acquiring patents in the above industries (Fischer and Henkel, 2012). In the context of patents and standards, a particularly important role is reserved for standard-essential patents (SEPs), which are also referred to as essential patents. These are patents that are required in order to implement a given standard, no matter whether the standard is set by a formally recognized standards body (such as the GSM standard for mobile telephony set by ETSI, or the MPEG video coding standards set by ITU), ${ }^{1}$ or by another type of organization. As a consequence, any company that implements that standard in a product or service will, by definition, infringe upon such patents if it does not have a licensing agreement with the patent owner. Because essential patents are particularly powerful and may give rise to abuse, such as refusal to license or hold-up pricing (Shapiro, 2001; Lemley and Shapiro, 2007), many standard-setting organizations (SSOs) have created special regimes under which members or other participants that own essential patents are required to disclose this, and any known essential patent owner is requested to commit itself to license essential patents to any implementer of the standard on the basis of fair, reasonable, and non-discriminatory (FRAND) prices and conditions. Many of the above lawsuits are actually concerned with these licensing commitments.

Companies that own SEPs enjoy a range of benefits, such as revenue-generating opportunities (as explained above, every implementer of the standard is by definition infringing, and thus by definition a potential licensee) and a good bargaining position for negotiating crosslicenses in order to gain access to both SEPs and non-SEPs owned by others. Moreover, at a higher level, Pohlmann et al. (2015) found that the ownership of essential patents boosts the financial returns of firms, while Aggarwal et al. (2011) provide empirical evidence for their positive influence on stock markets' returns. Given the attractiveness of owning such patents, companies that do not hold any (or believe they have too few) often try to purchase them, sometimes at very high prices. For example, in 2010 a consortium that included Apple, Microsoft, Ericsson, Sony, and BlackBerry acquired an important part of the former patent portfolio of now-defunct Canadian telecommunications firm Nortel for US\$ 4.5 billion. This portfolio is believed to contain a large number of essential patents for $4 \mathrm{G}$ mobile telecommunications. A year later, Google purchased Motorola Mobility for US\$12.5 billion, and thus acquired a patent portfolio valued by Google at US $\$ 5.5$ billion. $^{2}$ These transactions illustrate the value that companies attach to standards-related patents, though it should be noted that in both examples, the portfolios comprised both essential and non-essential patents.

\footnotetext{
${ }^{1}$ A list of abbreviations is provided at the end of this paper.

${ }^{2}$ Data on the basis of Google's Securities and Exchange Commission (SEC) filing. See CNET, July 25, 2012,

"Google: Motorola's patents, tech are worth $\$ 5.5$ billion."
} 
The question is how companies obtain essential patents in the first place. To answer this, one needs to consider the standardization process. Most SSOs create standards on the basis of technical proposals and suggestions from participants, and decide on the basis of consensus. In principle, any interested party can become a participant. Thus, in the case of telecommunications technology or IT, it is mainly companies that participate, although other stakeholders such as users, research organizations, or governments may also join in. A technical committee or a comparable group meets to discuss technical approaches to meeting the standards' design requirement, and to eventually decide, on the basis of consensus, on the final version of the standard. The committee may include technologies in the standard that are patented by the participants, but may also knowingly or unknowingly incorporate technologies covered by the patents of others. It is not unusual for a final telecommunications, consumer electronics, or IT standard to incorporate many, and sometimes thousands of, patented technologies: these are the essential patents. Although quite a few standards in areas other than those mentioned above also cover patented technology, their numbers of essential patents are typically much lower.

The inclusion of patented technologies in a standard can be a good thing, as these technologies may improve, for example, the standard's performance, cost-effectiveness, or environmental friendliness. In such cases, the costs of essential patents (i.e. the licensing fees and the associated costs, such as the resource-consuming licensing negotiation processes) may be worth the additional value of the standard. However, if such patents are included without their contributing substantially to the standard's value, it could be considered suboptimal from the public's perspective in terms of social welfare (although perhaps optimal from the perspective of an individual patent owner). In recent years, several observers have raised concerns about the undesirable inclusion of patented technologies. Even insiders have expressed concerns about the standard-setting process, during which parties can propose technologies:

“... just for getting patented technology into the standard rather than to improve the standard [...] No mechanism exists to determine whether a patent claim brings a standard forward (real innovation) or just tries to get a patent into the standard in order to make money.",

\footnotetext{
${ }^{3}$ Presentation by Dirk Weiler, chairman of the ETSI General Assembly and chairman of ETSI's IPR Special Committee, titled "Standards Related Patent Quality: A view from a standardisation organization." Presented at the EC/EPO Workshop on "Tensions between intellectual property rights and standardisation: reasons and remedies." Brussels, November 22, 2010. Retrieved January 3, 2011 from http://ec.europa.eu/enterprise/sectors/ict/files/ictpolicies/5 weiler en.pdf.
} 
One such strategy was recently outlined at a public conference by a former director of the research laboratory of a large, multinational company. ${ }^{4} \mathrm{He}$ explained how he would send staff to a standardization meeting, and that right after the meeting, they would brainstorm in the hotel room about how to combine elements that had been mentioned by other participants, and then immediately prepare patent applications for these (see Section 3 for more about this process). During standardization meetings, the authors also saw how companies were strategically filing patents during and just before the meetings, in order to have these technologies included in the specified standard.

In this study, we investigated whether participants in standardization processes indeed conducted "just-in-time patenting" by patenting technologies with low technical merit (that thus contribute little to the standard) just before a standardization meeting, and then attending that meeting to negotiate inclusion of the technology into the standard.

\section{Existing literature on standard-essential patents}

Problems that arise as a result of the inclusion of patented technologies in standards have been a topic of research for more than a decade. Much of the focus of this research has been on the effects of such technology inclusion on the market and on competition, including concerns about patent holdup, royalty stacking, and ambush or patent blocking (see, e.g., Lemley and Shapiro, 2007; Bessen, 2004; Farrell et al., 2007; Lindsay, 2012; Geradin et al., 2008; Sidak, 2009; Lerner and Tirole, 2015; and a 2014 article also by Josh Lerner and Jean Tirole in Science). The societal and policy relevance of this phenomenon is reflected in recent studies by the US National Academies of Science (Maskus and Merrill, 2013), reports by the Federal Trade Commission (e.g., FTC, 2011), studies conducted for the European Commission (e.g., Blind, 2011; Bekkers, 2014), investigations by the European competition authorities (Buehler et al., 2014), and publications of standards-setting organizations (SSOs) themselves (e.g., ITU, 2014). The competition and antitrust concerns related to essential patents are also summarized in a recent special issue of the Antitrust Bulletin (see Besen and Levinson, 2012) and in a book published by the American Bar Association on the antitrust aspects of standards setting (Kobayashi and Wright, 2010).

The question as to how patented technology becomes included in standards in the first place has only recently received attention. Related questions concern how SSOs select technologies

\footnotetext{
${ }^{4}$ Reference available from the authors, upon request.
} 
for their standards, and how firms promote their own patented technology for inclusion in those standards.

Rysman and Simcoe (2008) observed that, on average, patents disclosed as essential have a higher forward citation score than comparable, non-essential patents. This also applies after correcting for endogeneity, which is a risk here because the mere fact that patents are essential (or disclosed as essential) may result in increased citation performance. Rysman and Simcoe's findings can be interpreted as SSOs being able to select and integrate valuable technologies. Bekkers et al. (2011) studied different determinants of patents that were disclosed as essential by their owner. In line with the conclusion of Rysman and Simcoe, they found that patents with a high value ("technical merit") have an increased likelihood of being disclosed as essential. However, whether or not the patent holder was an active participant in the standardization meetings was found to be a much stronger determinant. The latter finding suggests that the strategic behavior of firms plays an important role in the technology selection processes at SSOs. The degree to which firms have opportunities to influence choices within the SSO was investigated by Dokko and Rosenkopf (2010), who showed that companies that own patents have a stronger influence on the decisions taken in standardization processes.

In a recent paper, Ganglmair and Tarantino (2014) present a theoretical model of a "conversation" between two agents that contribute ideas to a product or technology. Simultaneously, there is information asymmetry between the two agents in their model, because the ideas of the first might be patented, while the second does not know this as a certainty (hence the paper's title "Conversation with Secrets"). In their paper, this model is specifically applied to the standards-setting context. They show that a holder of patented technology has incentives to continue its involvement in the conversation for as long as possible, and to keep contributing technologies as long as it has some to contribute, to prevent the preemptive termination of the conversation. Even in the absence of SSO rules, the patent holder would still have incentives to disclose to the second agent that its technologies are patented. As a result, the asymmetry of information is reduced. However, the authors found that the strength of the incentive to disclose depends on the assumed prior belief of the second agent about whether patents exist. Ganglmair and Tarantino also discuss some cases in which SSO participants remained vulnerable to ex-post rent. For these reasons, they eventually suggest that SSO IPR policies with license commitments (such as FRAND) are useful to deal with situations in which their assumptions are not met. In the context of the inclusion of patented technologies, this paper underlines the importance of active involvement in and technical contributions to the standard-setting process. 
Other recent research studied the ways in which informal consortia influence technology decisions in standards setting. In this view, consortia are complementary to, rather than substitutes for, SSOs. The idea is that a group of selected SSO members coordinate their $\mathrm{R} \& \mathrm{D}$ efforts and align their strategies with regard to the SSO process. In her study on the standardization of the 3G W-CDMA standard, Leiponen (2008) focused on the role of private alliances and industry consortia. Firms that are part of such alliances and consortia increase their chances of having their own patented technical contributions included in the standard. In a later study, Delcamp and Leiponen (2014) examined whether participation in such groups increased the likelihood that these participants would start to cite each other's essential patents. When studying the $3 \mathrm{G} \mathrm{W}$-CDMA standard, they found that the centrality of a firm in such consortia has a positive effect on the forward citation score, with stronger effects for technical consortia (as opposed to marketing consortia). A limitation of their approach, however, is that it cannot indicate whether the result really is due to knowledge flow, or to the coordination of innovation within consortia, or is the result of strategic conduct. The idea of the role of consortia was recently followed up by Baron et al. (2014), who studied how the creation of ad hoc consortia of SSO members impacted R\&D failure problems in standardsetting contexts. In their view, consortia help smaller groups of firms to align their positions on a common technology roadmap. Concurrently, these firms can enhance their R\&D collaboration and increase their chances of influencing decisions in the SSO itself. They conclude that such consortia result in an increase in innovation when the SSO setting is characterized by a public good regime (a regime in which incentives to innovate are primarily driven by expected sales of standard-compliant products). However, they found that this effect is weakened or even reversed when the SSO setting is characterized by a rent-seeking regime, in which licensing revenues are sought to cover R\&D investments. This latter finding raises concerns about the negative effects of standardization on innovation.

Focusing more on the individual piece of knowledge and the people who created that knowledge, Kang and Motohashi (2014) investigated the role of the inventors of standardessential patents. They found that when the inventor of a specific patent is present at standardsetting meetings (as opposed to other representatives of the patent owner being present), the likelihood of that patent becoming part of the standard increases. This refines our knowledge of the importance of participation and contribution: not only does the active involvement of the firm play a role, but so too does the specific involvement of the inventor, who is the technical expert. 
Other authors have tried to explain the existence or determinants of essential patents by indicating firms' strategies that rely on specific features of the patent system. One possible strategy is that firms use continuation patents to obtain patents that are essential to technical standards, as argued by Omachi (2004). Along the same line of thought, Berger et al. (2012) found that patent applications that are eventually disclosed as standard-essential are amended more often than other, otherwise comparable patents. Firms arguably amend these patents to add claims to the patents that will eventually be essential to implement the standard.

The literature discussed above teaches us a number of important things about the inclusion of patented technology in standards. Key elements are the technical merit of candidate technologies (Rysman and Simcoe, 2008), the active involvement in and contribution to the standardization process (Ganglmair and Tarantino, 2014; Bekkers et al., 2011), the role of inventors (Kang and Motohashi, 2014), and strategies to form smaller groups that align their interests (Baron et al., 2014; Delcamp and Leiponen, 2014). Still, none of the existing literature focuses on the actual process of technology inclusion in the SSOs themselves. The purpose of this study was to address this research gap by conducting an empirical analysis of the standard-setting process itself, focusing on firms' strategies to have their own, patented technologies incorporated into the standard. One of the novel elements we introduce into the discussion is that of timing: contrary to most of the existing studies, we believe that timing plays a major role in the technology inclusion process.

\section{Hypotheses about essential patents and the standardization process}

Standardization is a voluntary process, in which interested parties come together and try to reach consensus about the exact content of a standard. The set of participants can be quite heterogeneous (Cargill, 1998) and different factors can drive their participation decisions (Gandal et al., 2007). Some of these parties may be companies that are prospective implementers of the standard; others are technology developers, end users, intermediate users (such as network operators in telecommunications), and component suppliers (such as makers of chip sets or software). In addition, other stakeholders, such as national governments or regulators, may participate. The various participants have different preferences, depending on their market position, their technological strengths and weaknesses, or the preferences of their clients, for example.

SSOs are established to facilitate the standardization process, but it is important to stress that standards are created by participants, not SSOs themselves. To secure such basic principles as 
openness and neutrality, and to ensure that their activities are not considered collusive or anticompetitive by competition or antitrust authorities, SSOs have developed sets of rules that are usually binding upon both their members and the participants. These sets include rules on essential patents, and generally require members and participants to disclose such patents (i.e., to inform the SSO when a party believes it owns such patents). Most policies also request essential-patent owners to make a commitment to license these patents under certain conditions (such as FRAND: "fair, reasonable and nondiscriminatory conditions").

Nevertheless, there is quite some variety in the rules formulated by SSOs. Lemley (2002) was among the first to analyze this institutional variety, while, later, Chiao et al. (2007) empirically explored SSOs' policy choices. A comprehensive and up-to-date review is provided in a recent report commissioned by the US National Academies of Science (Bekkers and Updegrove, 2012).

As discussed in the introduction, an essential patent is a patent that covers a technology that is required in order to produce a device that implements the standard. In other words, there is no alternative but to use this patented technology. Thus, essentiality depends on the exact scope of the patent (defined by the precise language used in the claims of the patent) and on the exact content of the standard (the wording of its specifications). So, when does a patent become essential? A number of stylized scenarios are shown in Table 1.

In the first scenario, the people who are drafting a standard may include a technology that was developed and patented long before discussions on the standard started. They might do so because they realize that this existing, patented technology is the best approach, or perhaps even the only way to create a standard that satisfies the agreed functional specifications. For example, it might increase performance, result in cost-effective devices, reduce energy consumption. Patented technologies with extraordinary technical merit are likely to be recognized by all participants and do not necessarily require the patent owner to promote the inclusion of the technology.

In the second scenario, the standard is being worked upon, but technical challenges or tradeoffs arise. In response, participants conduct additional research and use their knowledge to address these challenges. Some participants may come up with very original and creative solutions, for which they might immediately apply for patents. In this case, the patent filing is parallel in time to the standardization effort.

In the third and last scenario, companies apply for patents and try to have their technology included in the standard, even though it does not offer the standard significant improvements 
or technical merit. They may bargain with other participants to gain support for inclusion, possibly by offering them favors in return, such as support for the technologies proposed by them. There are strong incentives to do so because, as we have seen, owning an essential patent brings major advantages. Regardless of whether the patent has considerable technical merit, the advantages are there to enjoy: the mere fact that the specification of the standard is written in such a way that it overlaps with the language in the patent claim is sufficient.

Table 1. Stylized scenario for technology inclusion

\begin{tabular}{lcc}
\hline Scenario & $\begin{array}{c}\text { Time lapse between patent } \\
\text { application and technology } \\
\text { inclusion in standard }\end{array}$ & $\begin{array}{c}\text { Technical } \\
\text { merit }\end{array}$ \\
\hline $\begin{array}{l}\text { 1. Technical committee decides to include technology that } \\
\text { has long been patented }\end{array}$ & Long & High \\
$\begin{array}{l}\text { 2. Work in technical committees raises technical challenges } \\
\text { or trade-offs, and participants engage in additional R\&D, } \\
\text { possibly resulting in patented technology that is } \\
\text { incorporated in the standard }\end{array}$ & High \\
$\begin{array}{l}\text { 3. Participants "push" their own, patented technologies } \\
\text { into the standard, even though the technologies have little } \\
\text { merit. They may bargain with other participants for } \\
\text { support of inclusions, possibly offering favors in return. }\end{array}$ & Short & Low \\
\hline
\end{tabular}

In this paper, we are interested in the third scenario, and what we call "just-in-time patents." To be more precise, this term refers to patents for which (1) the timing of the patent application is aligned with the occurrence of standardization meetings, (2) the patent owner participates in the meeting to negotiate its technology into the standard, and (3) the patent is of relatively low technical merit. Below, we discuss the third scenario in more detail, and present the hypotheses that allowed us to measure its existence.

Ganglmair and Tarantino (2014) provide a basis to understand some specific elements of the just-in-time patents phenomenon. As discussed in Section 2, they found that what they call "secret" holders (i.e. owners of patents that have not yet been published) have incentives to continue their involvement in the "conversation" and incentives to reduce information asymmetry. Translated to the standard-setting context, this means that patent holders have incentives to participate in standardization meetings and to disclose any essential patents they own. If they own multiple patents, they may "bring in" these patents during future meetings to prolong the discussion for as long as possible, which, according to Ganglmair and Tarantino, would be to their advantage. The first step in the just-in-time patenting strategy, however, is to apply for patents for technologies that could potentially be included in the standard. The actual merit of the technology is a lesser concern; what is important is that the patent is applied for in time before a standardization meeting. In fact, a provisional 
application at the USPTO (which can act as a basis for the priority date for a formal patent application) is sufficient at this stage. Companies can wait until just before the standardization meeting to ascertain the technology that best meets their goals, and can submit a provisional patent application, and also send submissions to the standards-setting committee. In most SSOs (including 3GPP, on which we focused for our empirical data), the latter documents are distributed to the other members. As the meeting draws closer, more information is available on the likely technological direction to be taken, as more companies will have submitted documents and proposals (because, in line with the Ganglmair and Tarantino theory, these other companies also see benefit in reducing information asymmetry). As a result, we hypothesize that companies that employ just-in-time strategies are likely to apply for patents just before the meetings in question, to benefit as much as possible from the information made available by others. Furthermore, because bargaining for the inclusion of their technology is a key part of the just-in-time strategy, we expect to find this conduct especially among companies that actually participate in the meeting. On the basis of the above, we formulated the following hypothesis:

Hla: Among meeting participants, there is an increased intensity in essential-patent filing just before a standardization meeting, compared to the idle period between meetings.

Alternatively, firms could apply for patents during the actual meetings, having been inspired by the ideas expressed by other participants, for instance, or by combining or recombining such ideas. Companies might even "steal" by filing for patents on ideas expressed by others. While at first such stealing seems to go against the basic principles of patent law, where ideas cannot be patented after they have become part of the public domain, documents and information shared in standards-setting are generally not considered public and are therefore not part of the prior art (see Section 5 for a more detailed discussion on this aspect). While the above strategy of applying for patents during actual meetings can be used by participants, it can also be used by non-participants, since all meeting information and submissions by companies are instantly made available electronically to all members, regardless of actual meeting participation. On the basis of the above line of arguments, our second hypothesis was:

H1b: Among both meeting participants and non-participants, there is an increased intensity in essential-patent filing during a standardization meeting, compared to the idle period between meetings. 
While the above hypothesis considers those patents that are eventually disclosed as essential, it does not tell us about the likelihood that a given patent will become essential. As we have argued above, we expected that those who do participate in meetings increase this likelihood by pleading and bargaining (possibly offering other favors in return), whereas those who do not attend the meetings do not have this ability to increase the likelihood. Indeed, Bekkers et al. (2011) showed that patents owned by active participants in standardization meetings had a significantly higher likelihood of becoming essential. Such participation can be seen as strategic behavior. Our related hypothesis was:

H2. Patents applied for just before or during a standardization meeting have an increased likelihood of becoming essential patents.

The above timing phenomenon (H1a, H1b) is interesting, but could also be interpreted as a deadline effect, whereby firms submit patent applications just because they happen to be ready with the invention and decide to file a patent just before a meeting in which the idea might be discussed. In addition, the likelihood effect (H2) is not necessarily a concern in itself, as long as the patented technology that is included in the standard brings significant benefits. The real concerns arise when such patents are of relatively low technical merit and do not benefit the standard. Forward patent citations are, arguably, the best proxy for technical merit for a study of this type (we will come back to this measurement later). While earlier studies have shown that, on average, essential patents receive more citations than nonessential patents that are otherwise comparable (e.g., Rysman and Simcoe, 2008; LayneFarrar, 2011), we predicted that there are differences between different classes of essential patents. More specifically, in line with the strategic meeting participation as found by Bekkers et al. (2011), we expected that essential patents filed just before or during a meeting have a lower technical merit (i.e., receive fewer citations) than essential patents filed at any other point in time. Our resulting hypothesis was:

\section{H3. Standard-essential patents of meeting participants applied for just before or during a standardization meeting have a lower technical merit than other standard- essential patents.}

We furthermore expected the above effect to hold only for meeting participants; for nonparticipants, we did not expect any technical merit differences related to meeting timing.

Finally, it might be that incentives to engage in just-in-time patenting differ as a result of firms positioning themselves differently. There might be differences resulting from their 
business model (e.g., upstream versus downstream in the knowledge market), and there might be differences between firms that have been part of the "essential-patent game" for many years versus newcomers. While we were interested in learning about such differences, we had no specific a priori expectations here, so we did not postulate any hypotheses.

We wish to note that, for all the above hypotheses, when we speak of "essential patents," we mean those patents that are claimed (disclosed) by their owners as essential, since we have no objective measure to test whether they actually are essential. ${ }^{5}$ Moreover, note that such claims are usually made only after it becomes clear what the standard actually entails, which may be long after the actual meeting. So, in this paper, when we talk about "essential patents," we specifically mean patents that are eventually disclosed by their owner as essential to the standard. Finally, throughout this paper, we use "patents" to refer to both granted patents and patent applications.

\section{Data and findings}

To test our hypotheses, we turned to the development of the W-CDMA ${ }^{6}$ and LTE standards, the most successful global technologies for $3 \mathrm{G}$ and $4 \mathrm{G}$ mobile telecommunications, respectively. Their standardization effort took place in an organization called the Third Generation Partnership Project (3GPP), which is a collaboration between the most prominent regional SSOs in this field, including Europe's ETSI, Japan's ARIB, and South Korea's TTA. The W-CDMA and LTE standards - the direct successors to the successful 2G GSM standard - already have over 1.3 billion users worldwide; ${ }^{7}$ a number that is expected to grow considerably as more advanced services are adopted in both developed and developing countries around the globe.

The development of these standards was anything but static. The first version of W-CDMA was released in early 2000, and the standard saw numerous improvements in later years. Over time, new specifications were added, such as HSPA, to improve data transmission speeds. In fact, over a 10-year period, these data transmission capacities gradually increased to become

\footnotetext{
${ }^{5}$ Attempts to determine the actual essentiality of larger sets of disclosed patents have been heavily criticized; see Goodman and Myers (2005) and the critique by Martin and De Meyer (2006). See also the critical discussion in Mallinson (2011), who shows that two studies with a similar approach arrived at totally unrelated results in terms of determining actual essential patents.

${ }^{6}$ In Europe, the W-CDMA standard is also known as UMTS, although the latter has a somewhat wider technical scope than the former. Worldwide, the W-CDMA standard is also known as $3 \mathrm{GPP}$, after the name of the partnership.

${ }^{7}$ Based on late 2013 market data by the Global Mobile Suppliers Association (GSA).
} 
almost a thousand-fold higher than the original version of this $3 \mathrm{G}$ standard. ${ }^{8}$ The development of the 4G LTE standard was an evolutionary one, smoothly integrated in the existing activities and achieving an increasingly higher performance over time.

These constant improvements in the W-CDMA and LTE standards, which were discussed during numerous meetings over a period of more than 10 years, made this a very attractive case study to test our hypotheses. In addition, the availability of data on meeting participation and essential patents made this case particularly suitable. Furthermore, the nature and volume of those data (77 meetings quite regularly spaced in time, attended by 939 individual participants representing 53 firms, and over 14,000 patents in the relevant technology area, of which 988 were claimed to be essential) also made this an attractive case to test the hypotheses.

For this study, we collected data on the meetings of the 3GPP RAN1 group, which is the group responsible for the physical layer of the radio interface, being the most central element of the standard. We collected data on all of this group's meetings, from the first (January 21$22,1999)$ to what is known as the 60th meeting (February 22-26, 2010). There were a total of 77 meetings in this period (the numbering by $3 \mathrm{GPP}$ is not always sequential; there might be a 27bis meeting, for instance), so the average spacing between the start days of meetings is slightly under two months (52 days). The meetings themselves lasted an average of 4.5 days. For our study, we also explicitly considered the seven-day period preceding each meeting, which we call the "pre-meeting period." As discussed below, we also performed robustness checks for other lengths of the pre-meeting period.

A schematic diagram of the timing of meetings is presented in Figure 1.

Figure 1: Schematic presentation of 3GPP RAN1 meeting occurrence

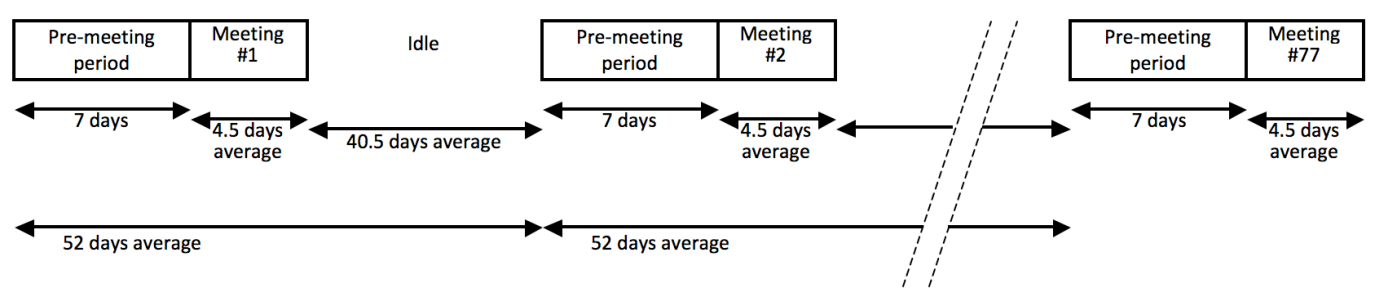

\footnotetext{
${ }^{8}$ The first version of the 3 GPP standard, known as R99, included specifications for data transport up to a transmission speed of $384 \mathrm{Kbit} / \mathrm{s}$. Release 11 of this standard, which was finalized in the third quarter of 2012, includes a data transmission mode known as HSPA+, which provides speeds of up to $337 \mathrm{Mbit} / \mathrm{s}$. Speeds in LTE and LTE Advanced are much higher.
} 
Data on claimed essential patents were retrieved from the Disclosed Standard Essential Patents database (dSEP). ${ }^{9}$ This database, which was first presented in 2012 at the NBER conference on Standards, Patents and Innovation, includes harmonized data on over 40,000 patent disclosures at the main standardization bodies (Bekkers et al., 2012). The relevant W-CDMA and LTE entries in this database were matched with PATSTAT, the comprehensive patent database developed by EPO and OECD, providing us with, for example, detailed metadata on patents and their patent families and inventors. Additional data on firms' business models, home regions, etc. were obtained from other sources. We chose to do our analysis on the basis of US patents, because we had learned from participants in SSO processes that it is at the USPTO that just-in-time patents are applied for, using its provision application mechanism. While not requiring a formal patent claim, oath, or declaration, or any information disclosure (prior art) statement, such an application can be prepared very quickly and easily. It establishes an early effective filing date, giving the applicant up to 12 months to write a full, non-provisional application, and allowing the early priority date to be used for later applications at other patent offices around the world.

\subsection{The relationship between patent filing and meeting occurrence}

The first hypothesis relates to whether there is a cyclic pattern in patent filings, induced by the meeting schedule. Figure 2 shows our main findings. In it, the leftmost set of bars shows, the patenting intensity of the full set of firms (i.e., all companies that applied for patents that were eventually disclosed as essential to the standard) for the various periods. ${ }^{10}$ What we actually measured is whether the first application for a given patent - usually a provisional application - was filed during one of the three periods we distinguished. This information is reflected in the earliest priority date listed at the patent office for the patent in question. As can be seen, the patenting intensity in the pre-meeting periods is much (2.6 times) higher than that in the idle period between the meetings. ${ }^{11}$ The patenting intensity during the meeting is also higher than in the idle period, but the effect is less pronounced. The relatively low standard error values suggest that both are significant differences (we provide more formal testing below).

\footnotetext{
${ }^{9}$ Previously, this database was called Open Essential IPR Disclosure Database (OEIDD).

${ }^{10} 3 \mathrm{GPP}$ is a partnership between SSOs and does not have a membership structure as such. Members of the partner organizations have the right to participate in 3GPP meetings. Although our set of "all firms" includes essential patent owners that are not members of any partner organization, this situation is rare: almost all essential patent owning firms are members of at least one of the partnering organizations.

${ }^{11}$ In our data, "idle" refers to the periods between meetings, not the periods preceding the very first meeting or the period after the very last meeting considered. Had we included these two latter periods, our data would also include, for example, some very valuable patents that were applied for long before the series of meetings took place, and this could have substantially biased our measurements.
} 
Figure 2: Average number of patent applications per week in relation to meeting occurrence

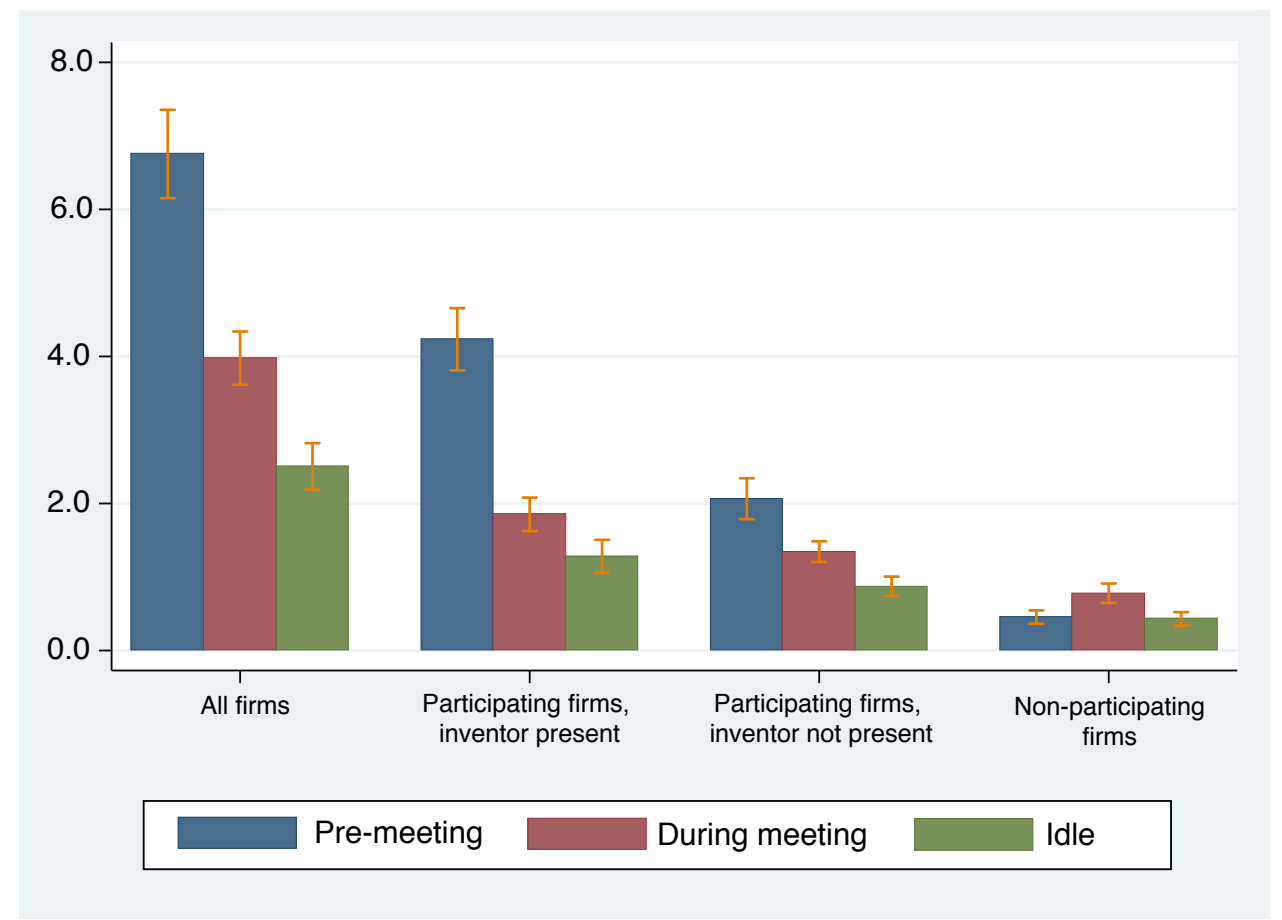

Note: Bar lengths represent the average number of patent applications per week. The orange lines show one standard error above and one standard error below the mean.

In order to obtain a better understanding of what causes these effects, we broke these patent filings down into three categories, as shown in Figure 2. The first category comprises patents of 3GPP participating firms whose listed inventor was actually present at the meeting. For this category, the effect is the strongest: patenting intensity during the pre-meeting period is 3.2 times higher than that during the idle period. Patenting intensity during the meeting is somewhat higher than in the idle period. The second category comprises 3GPP participating firms not represented at the meeting by the listed inventor of a patent, although other colleagues had attended it. For this category, the effect for the pre-meeting period still is clearly present, but less strong. However, there is no real difference between patenting intensity during the meeting and that during the idle period. Finally, for the category of firms that did not participate in the 3 GPP meetings, we see another, interesting pattern: the premeeting period shows scarcely any increase in patenting activity, but during the meeting (which they are not attending) their patenting activity doubles.

Table 2 summarizes the data underlying Figure 2. As indicated, we assumed the pre-meeting period to be seven days, which we believe accurately captures the effect we are considering, given that the total gap between meetings was on average 47.7 days. We also performed 
checks for other assumed lengths of the pre-meeting period, and found that our results are robust. $^{12}$

Table 2: Claimed essential patents filed before, during, or after a meeting

\begin{tabular}{|c|c|c|c|c|c|}
\hline \multirow[b]{2}{*}{ Period (1) } & \multirow[b]{2}{*}{$\begin{array}{l}\text { Cumulative } \\
\text { length in } \\
\text { weeks (2) }\end{array}$} & \multicolumn{4}{|c|}{ Claimed essential patents applied for within that period } \\
\hline & & By all firms (3) & $\begin{array}{l}\text { By participating firms, } \\
\text { inventor(s) present at } \\
\text { meeting (4) }\end{array}$ & $\begin{array}{l}\text { By participating firms, } \\
\text { inventor(s) not present } \\
\text { at meeting (5) }\end{array}$ & $\begin{array}{l}\text { By non- } \\
\text { participating } \\
\text { firms (6) }\end{array}$ \\
\hline Pre-meeting & 77.0 & 520 (6.8/week) & 326 (4.2/week) & 159 (2.1/week) & 35 (0.5/week) \\
\hline During meeting & 51.3 & 204 (4.0/week) & 95 (1.9/week) & 69 (1.3/week) & 40 (0.8/week) \\
\hline Idle & 452.9 & 1170 (2.6/week) & 580 (1.3/week) & 395 (0.9/week) & 195 (0.4/week) \\
\hline Total & 581.1 & 1856 (3.2/week) & 988 (1.7/week) & 608 (1.0/week) & 260 (0.5/week) \\
\hline
\end{tabular}

Whereas we would, of course, like to compare our data to the null hypothesis that patents are filed at the patent office in a random fashion over time (e.g., a Poisson-like distribution), we know that patent application rates vary over specific periods of the year. Performing a simple analysis of all patents filed at the USPTO between 1976 and 2010, we observe, for instance, that $23.2 \%$ of all patents were filed on a Monday, whereas only $18.2 \%$ were filed on a Tuesday (and $0.045 \%$ on a Sunday). We also noted, for instance, that June sees considerably more patent applications than January (9.6\% versus $7.1 \%)$, and that there is a rather remarkable peak in week 24 , when the filing rate is almost $40 \%$ higher than the average of all weeks of the year. Such patterns could have distorted our findings. If there were any specific relationship between the dates of the standardization meetings and the peaks and troughs in overall patent filing intensity, our results might have simply reflected these more general trends. To correct for such possible effects, we performed a regression in which the dependent variable was the number of patent filings per week (i.e., a count variable), and the explanatory variables were dummies for the 52 weeks of the year. We also entered our explanatory variables (dummies) for whether the eventually claimed essential-patent application coincides with the pre-meeting period or the meeting period - the baseline being in the "idle" period. Because in our dependent variable, the variance is about twice as large as the mean, we used a negative binomial regression instead of a Poisson regression (estimated alpha coefficient is

\footnotetext{
${ }^{12}$ More precisely, we have calculated the results for pre-meeting periods of 3, 5, 7, and 9 days. The last three in this set all show substantial and significant differences between the pre-meeting and idle period patent intensity. The period of three days does not, but we believe this is probably because the meetings in question mostly started on a Monday, and thus most of the three-day periods are predominantly made up of Saturdays and Sundays, on which very few applications are submitted to the patent office in the first place.
} 
not equal to zero). ${ }^{13}$ Models 1 and 2 in Table 3 show the results. We conclude that our earlier results remain stable and do not lose significance after correcting for the week of the year. We performed a similar analysis for days of the week (Monday to Sunday) and found stable results as well (Models 3 and 4, Table 3).

Table 3: Patents applications received per week (Models 1 + 2) and per day (Models 3 + 4)

\begin{tabular}{lcc}
\hline & Model 1 & Model 2 \\
\hline Pre-meeting $^{\text {(a) }}$ & 0.9445 & 1.0176 \\
& {$[7.78]^{* * *}$} & {$[7.31]^{* * *}$} \\
During meeting $^{(a)}$ & 0.1857 & 0.2688 \\
Dummies for the $52^{*}$ & {$[1.43]$} & {$[1.88]^{*}$} \\
weeks of the year & No & Yes \\
Constant & 0.9444 & 0.1048 \\
\hline Observations & {$[18.03]^{* * *}$} & {$[0.14]^{* * *}$} \\
\hline
\end{tabular}

\begin{tabular}{lcc}
\hline & Model 3 & Model 4 \\
\hline Pre-meeting $^{\text {(a) }}$ & 1.0230 & 1.024 \\
& {$[11.04]^{* * *}$} & {$[11.61]^{* * *}$} \\
During meeting $^{\text {(a) }}$ & 0.5448 & 0.2430 \\
Dummies for the $_{\text {7 days of the week }}$ & No & {$[2.30]^{* *}$} \\
Constant & -1.0464 & Yes \\
\hline Observations & {$[-25.30]^{* * *}$} & {$[-12.0350$} \\
\end{tabular}

Negative binominal regressions. Dependent variable is the number of patent applications (later claimed as essential) received in any given week (Models 1 and 2) or on any given weekday (Models 3 and 4). Values in brackets are z-values. Significance levels: * $p<0.1, * * p<0.05, * * * p<0.01$. Weeks run from Monday to Sunday. Note: (a) Baseline value is the "idle" period.

We can therefore accept H1a: There was an increase in essential patent filing by meeting participants just before a standardization meeting, compared to the idle period. As shown above, the effect is both substantial (an increase in intensity by a factor of three) and significant; this held when we checked for other possible explanations. We also established that this effect is absent for non-participants. We can therefore also accept H1b: there was an increase in essential patent filing by both meeting participants and non-participants during a standardization meeting. Although this effect is less strong than the previous one, it is still sizable and significant.

\subsection{The effect of meeting participation on the likelihood of patent inclusion}

As argued, standardization meetings offer participants opportunities to have their patents incorporated into the standard. In other words,, by making technical submissions that are covered by their own patents, proposing their patented technologies at the meeting, and bargaining with other participants about the content of the standard, they can attempt to have the final standard include their own, patented technologies.

${ }^{13}$ A Poisson regression produces virtually identical results. 
The question is how effective meeting participants are at having their patented technology included in the standard. This question is the core of hypothesis H2. To address it, we constructed a dataset of all patents and patent applications at the USPTO by inventors who were identified as having participated in one or more of the 3GPP meetings we considered. We further restricted this search to those IPC subclasses (e.g., "H04B") that also appear in the set of essential patents for this standard. ${ }^{14}$ By restricting ourselves to these inventors and these IPC subclasses, we believe that we selected inventions that were potential candidates for inclusion in the standard under consideration. ${ }^{15} \mathrm{We}$ additionally restricted the search to the years 1999 to 2010, the period in which our sample meetings took place. These selections resulted in a set of 14,524 patents that can be considered a "pool" of patents that may potentially be essential to the $3 \mathrm{GPP}$ standard. Of this total, 988 patents were claimed to be essential; the remaining 13,536 patents were eventually not. In this respect, this dataset differs from the dataset we used in the previous section, which included only essential patents. Using this new dataset, we studied the determinants of whether a patent is disclosed by its owner as standard-essential.

Table 4 presents our findings regarding the determinants of patent essentiality. In the logit regression results, the dependent variable is whether or not a patent has been disclosed as essential. Model 1 tests hypotheses H1a and H1b. For patents applied for just before a standardization meeting, we see a significant and strong positive effect, whereas for patents applied for during the meeting, the effect is not significant. We also added a number of control variables to test how robust our findings are. Since companies with a large patent stock may have different strategies compared to those with a small patent portfolio, we included the total patent stock of the assignee in Model 2. It proved not to be significant. In Model 3 we did the same thing for the stock of declared essential patents only. This variable does have a significant affect, but does not affect the core hypotheses (see Model 4).

\footnotetext{
${ }^{14}$ In a few cases, we also added IPC group numbers to the IPC subclasses (e.g., H04N01) because the subclass in question was too broad for our purpose of identifying potential $3 \mathrm{G} / 4 \mathrm{G}$ patents.

${ }^{15}$ Had we selected only on technology classes, the resulting set might have been too broad, as IPC subclasses often cover a broad range of inventions many of which are not considered real candidates for a given standard. Had we selected only on inventors, again the resulting set might have been too broad, as inventors might work in multiple subject areas.
} 


\begin{tabular}{|c|c|c|c|c|}
\hline & Model 1 & Model 2 & Model 3 & Model 4 \\
\hline Patent filed during pre-meeting period & $\begin{array}{c}0.5301 \\
{[7.32]^{* * *}}\end{array}$ & $\begin{array}{c}0.5300 \\
{[7.32]^{* * *}}\end{array}$ & $\begin{array}{c}0.5519 \\
{[7.50]^{* * *}}\end{array}$ & $\begin{array}{c}0.5456 \\
{[7.41]^{* * *}}\end{array}$ \\
\hline Patent filed during meeting period & $\begin{array}{c}0.0354 \\
{[0.31]}\end{array}$ & $\begin{array}{c}0.0341 \\
{[0.30]}\end{array}$ & $\begin{array}{c}0.0617 \\
{[0.53]}\end{array}$ & $\begin{array}{c}0.0665 \\
{[0.58]}\end{array}$ \\
\hline Patent stock of assignee $(\log 10)$ & & $\begin{array}{c}-0.0288 \\
{[-0.42]}\end{array}$ & & $\begin{array}{c}0.1671 \\
{[2.24]^{* *}}\end{array}$ \\
\hline Stock of essential patents of assignee & & & $\begin{array}{c}0.0078 \\
{[17.95]^{* * *}}\end{array}$ & $\begin{array}{c}0.008 \\
{[17.67]^{* * *}}\end{array}$ \\
\hline Constant & $\begin{array}{c}-2.7672 \\
{[-64.06]^{* * *}}\end{array}$ & $\begin{array}{c}-2.652 \\
{[-9.50]^{* * *}}\end{array}$ & $\begin{array}{c}-3.7119 \\
{[-48.64]^{* * *}}\end{array}$ & $\begin{array}{c}-4.4089 \\
{[-13.67]^{* * *}}\end{array}$ \\
\hline $\mathrm{N}$ & 14524 & 14524 & 14524 & 14524 \\
\hline
\end{tabular}

Logistic regression, dependent variable is dummy whether the patent is claimed essential. Values in brackets are zvalues. Significance levels: ${ }^{*} p<0.1, * * p<0.05, * * * p<0.01$

Turning now to hypothesis H2 ("Patents applied just before or during a standardization meeting have an increased likelihood of becoming essential patents"), we can only partly accept this proposition: patents applied for just before a standardization meeting indeed have an increased likelihood of becoming essential patents, and this effect remains remarkably robust after adding several relevant control variables. However, patents applied for during a standardization meeting do not have an increased likelihood of becoming essential patents.

\subsection{The technical merit of just-in-time patents}

One important question is whether the patents we took interest in are any different from "normal" patents, whose timing is not specifically linked to the standardization meeting. This was addressed by hypothesis H3 ("Standard-essential patents of meeting participants applied for just before or during a standardization meeting have a lower technical merit than other standard-essential patents"). We used forward citations ("incoming citations") as a proxy for the technical importance of a patent (Carpenter et al., 1981; Trajtenberg, 1990; Karki, 1997). The interpretation is relatively straightforward. Forward citations refer to existing knowledge (prior art) that is deemed relevant for patent examiners who are determining the novelty of a new patent application. In the USA, a Duty of Candor ${ }^{16}$ requires everyone involved with a patent application to disclose all publications they know of that may adversely affect the patentability of their invention. If a previously patented technology has high technical merit, in the future it is cited more often as relevant prior art. In this context, it does not really matter whether this citation was offered by the patent applicant, the applicant's patent attorney, or by

${ }^{16}$ Code of Federal Regulations, at 37 C.F.R. §1.56, known as "Rule 56." 
the patent examiner (here, we are not interested in knowledge flows). Although there have been long discussions on how good citations are as a predictor of the value of a patent (see, e.g., Gambardella et al., 2008 and Van Zeebroeck, 2011), and we acknowledge that forward citations have also been found to be correlated with a host of other factors that may suggest alternative interpretations of the same outcome variable, we believe forward citations are a much more direct indicator of technologically important patents, or "technical merit," which is what this paper is considering.

To obtain a reliable citation performance measurement, it is important to consider the distribution of incoming citations over time. Rysman and Simcoe (2008) showed that for claimed essential patents, this trail is longer than it is for otherwise identical, non-essential patents. It was therefore important to ensure that the patents we included in this analysis had had sufficient time to collect incoming citations. With this in mind, we selected all claimed essential patents or patent applications in our dataset with a priority date in 2005 or earlier (slightly over 1000 patents in our dataset meet that criterion). As we used patent citation data compiled in 2012, all these patents had had at least seven years to collect citations. Even the most recent patents in this selection had a well-developed citation trail, making us confident that our citation score is robust. ${ }^{17}$ Including more recent patents would have made the analysis more prone to error and biases. Note that our set of selected patents does not include patents with a priority date earlier than 1999, the year in which the first of our 77 standardization meetings took place. This is important, because earlier studies have found that claimed essential patents that precede the standardization effort often have a much higher citation score, being selected for their technological contribution, even though they are "old" (Bekkers et al., 2011). Excluding this group prevented unwanted bias in this respect. Finally, while our analysis included all citations, we also performed the same analysis with self-citations removed and found the outcomes are similar. Moreover, when we performed the analysis using a variety of earlier cut-off dates than 2005, we found similar results, suggesting that the citation score measurement is robust and not influenced by truncation biases.

Our data set includes patents of various age, and it is important to realize that older patents had had more opportunities to collect citations than younger patents. To correct for this, we followed the approach suggested by Jaffe and Trajtenberg (2002). For each priority year present in our dataset, we calculated the average citation performance of all patents

\footnotetext{
${ }^{17}$ Rysman and Simcoe (2008) estimated the citation trail on the basis of age since patent grant. After four years, an average essential patent has already collected $40 \%$ of all the citations it will receive over its lifetime. If we assume that the priority date of a patent lies three years before the grant date, then this $40 \%$ is reached seven years after the priority date.
} 
(regardless of whether they are essential) in the appropriate IPC technology subclasses. ${ }^{18}$ The score of any essential patent can thus be compared to the average citation score in that year. Since all our patents are in a relatively narrow set of technology subclasses, which display a rather similar citation performance, there was no need for a technology subclass correction.

Figure 3 shows the main results of our analysis. The bars in this graph represent the citation performance of claimed essential patents for the three time periods defined earlier in this paper. Firstly, all the scores are higher than 1 ; in other words, claimed essential patents have a higher citation performance than non-essential patents. As indicated, this finding is in line with earlier studies in this field. While it might be argued that the absolute citation score of essential patents may be the result of endogeneity rather than reflecting a higher patent value (see the literature review in Section 2), this is irrelevant, since our conclusions are based only on the comparison of groups of claimed essential patents, not on comparisons of claimed essential patents with non-essential patents. The citation scores of non-essential patents only serve as a base reference point in our study. Secondly, we observe that claimed essential patents by inventor participants applied for in the "pre-meeting" period have a much lower citation performance than the (larger) group of patents in the "idle" period. We observe a similar difference for the period during the meeting. We also note that the effect is present only for inventor participants (as suggested in the hypothesis); for other essential patent owners, patent citation performance is independent of timing.

\footnotetext{
${ }^{18}$ In the interest of computation time, we did not take the full population of all patents, but drew a large sample (approx. 10,000 patents, i.e., 10 times the size of the number of essential patents in the selection).
} 
Figure 3: Relative citation performance of claimed essential patents for three different periods

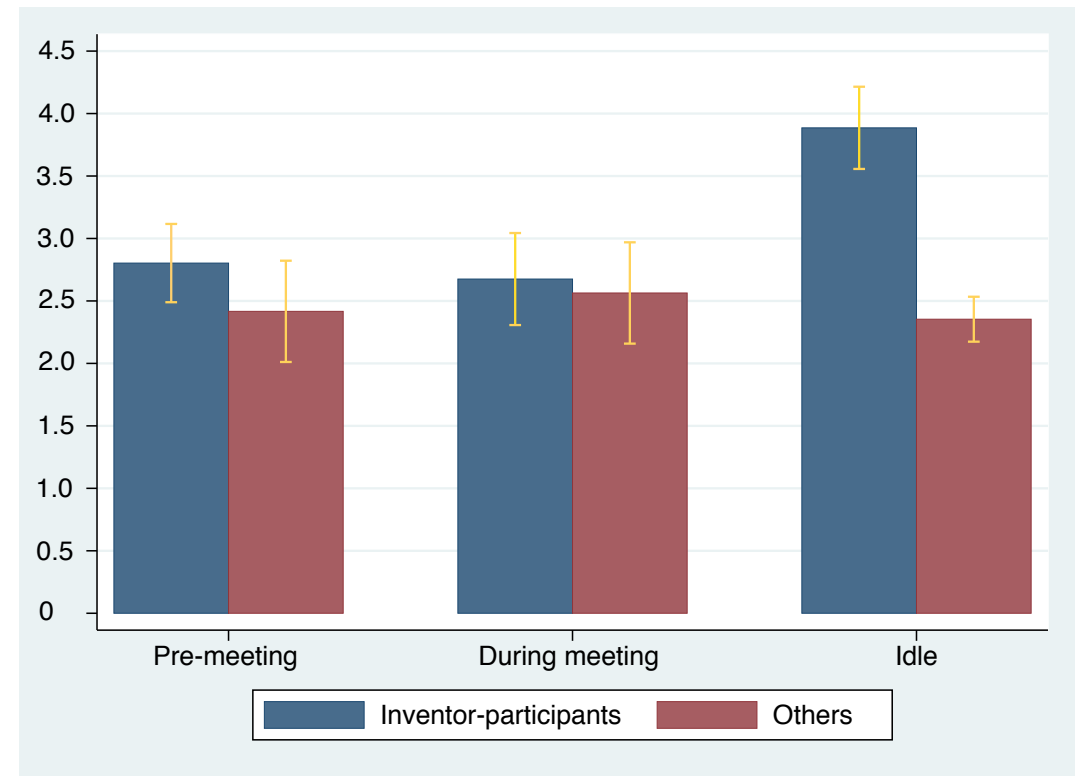

Note: Bar lengths represent the normalized average number of forward citations, where the value 1.0 refers to the average forward citation score of all patents (essential and non-essential) in the same year and same IPC technology subclass. The orange lines show one standard error above and one standard error below the mean.

On the basis of these findings, we can confirm hypothesis H3 ("Standard-essential patents of meeting participants applied for just before or during a standardization meeting have a lower technical merit than other standard-essential patents"): Claimed essential patents applied for by inventor participants in the week preceding a standardization meeting, and patents applied for during the meeting, have a significantly lower citation performance than claimed essential patents applied for by inventor participants at any other point in time. As expected, this difference is not present for non-meeting participants. 


\subsection{The type of firms that engage in just-in-time strategies}

The last part of our empirical analysis concerned the exploratory question as to which organizations engage in just-in-time patenting. Do all meeting participants do this to the same extent, or are there differences between specific classes of companies? We answered this question by studying the determinants of just-in-time behavior. For the patents and their filing moment, we used the same data we used for hypotheses $\mathrm{H} 1 \mathrm{a}(\mathrm{a} / \mathrm{b})$ and $\mathrm{H} 3$. We then identified the companies that own these patents (or, more precisely, the companies that submitted a disclosure stating that they believe they own an essential patent), and complemented our data with specific information on those companies. A full description of the data and the variables is included in Appendix A.

We complemented our company data in five steps. Firstly, we determined the business model that best characterizes the company (in the context of the industry we consider). While our original data distinguish nine distinct business models, ${ }^{19}$ for this analysis we reduced that to those companies that have an upstream business model (in the knowledge or product market) and those that do not. Secondly, we determined in which world region these companies originate - typically taking the region in which the firm's headquarters is based. Thirdly, we identified what we call "incumbent suppliers," namely the manufacturing companies that championed the preceding technology standard (2G GSM, which was in many ways the institutional predecessor of 3GPP). To identify those firms, we used the "number of units" that ETSI determines for each of its members (each member's contribution level and voting power is based on its number of units). For companies, the number of units is derived from the revenue they make from products that fall within the scope of ETSI's activities. We used the score from 1998 - a year from the 2G era, well before W-CDMA or LTE equipment came on the market. Fourthly, we considered the patent stock of companies in terms of both total patent stock (for any technology area) and the patent stock relevant to the 3GPP standards we focused on. Finally, we included the intensity of participation in the 3GPP meetings.

Before turning to the results, we must stress that because of the nature of these data, it is inevitable that some of the above variables are related to each other (see Appendix B for a correlation matrix). For instance, most upstream companies in our dataset originate in the

\footnotetext{
${ }^{19}$ These are: (1) pure upstream knowledge developer or patent holding company (excl. universities); (2) university / public research institute / state; (3) component suppliers (incl. semiconductors); (4) software and software-based services; (5) equipment supplier, product vendor, system integrator; (6) service provider (telecommunications, radio, television, etc.); (7) SSO, forum, and consortium, technology promoter (as patent owners); (8) individual patent owner; (9) measurement and instruments, test system. In our study, the dummy "upstream business model" includes categories (1) through (4).
} 
USA. In contrast, most incumbent suppliers originate in Europe (the "GSM champions"). The South Korean companies in our dataset have a much higher than average overall patent stock (because most of them are a type of large business conglomerate known as Chaebol), whereas Japanese companies have, on average, a much lower stock of SEPs. In the interpretation of our analysis below, we pay due respect to these interdependences. Nevertheless, we feel it is valuable to present this combined analysis, as it provides insight into which classes of companies embrace certain patenting strategies.

Our results are presented in Table 5, which shows the determinants of a patent strategy in which filings are done in the seven days preceding a standardization meeting (we performed the same analysis for filings done during the meeting, but omitted these from this paper as this strategy was found to be less pertinent in the sections above). In Model 1, we investigated business models and found that companies with an upstream business model are less likely to employ this type of patent strategy than downstream companies (i.e., vertically integrated firms). In Model 2, we considered the home region of these companies, where the baseline value of this variable is Europe. We found that just-in-time patenting is especially prevalent among European and South Korean firms, and less so among companies from the USA, Japan, China, and Canada. In Model 3, we entered both business model and home base. Given that upstream business models are found especially in the USA, it is no surprise that the significance of a USA home base completely disappears, while the other significant geographical relations remain. 
Table 5: Determinants of filing patents in the seven days preceding a standardization meeting

\begin{tabular}{|c|c|c|c|c|c|c|c|c|c|}
\hline & Model 1 & Model 2 & Model 3 & Model 4 & Model 5 & Model 6 & Model 7 & Model 8 & Model 9 \\
\hline $\begin{array}{l}\text { Upstream business } \\
\text { model }\end{array}$ & $\begin{array}{c}-0.2044 \\
{[-4.88]^{* * *}}\end{array}$ & & $\begin{array}{c}-0.2119 \\
{[-2.81]^{* * *}}\end{array}$ & & $\begin{array}{c}-0.2118 \\
{[-2.81]^{* * *}}\end{array}$ & & $\begin{array}{c}-0.3507 \\
{[-4.19]^{* * *}}\end{array}$ & & $\begin{array}{c}-0.3361 \\
{[-3.99]^{* * *}}\end{array}$ \\
\hline Home region USA ${ }^{\text {(a) }}$ & & $\begin{array}{c}-0.2795 \\
{[-4.91]^{* * *}}\end{array}$ & $\begin{array}{r}-0.1069 \\
{[-1.28]}\end{array}$ & & $\begin{array}{l}-0.106 \\
{[-1.13]}\end{array}$ & & $\begin{array}{c}-0.2808 \\
{[-2.51]^{* *}}\end{array}$ & & $\begin{array}{c}-0.3268 \\
{[-2.83]^{* * *}}\end{array}$ \\
\hline Home region $\mathrm{KR}$ & & $\begin{array}{l}-0.083 \\
{[-1.32]}\end{array}$ & $\begin{array}{r}-0.0764 \\
{[-1.21]}\end{array}$ & & $\begin{array}{r}-0.0754 \\
{[-0.98]}\end{array}$ & & $\begin{array}{c}-0.1603 \\
{[-1.50]}\end{array}$ & & $\begin{array}{l}-0.2066 \\
{[-1.87]^{*}}\end{array}$ \\
\hline Home region JP & & $\begin{array}{c}-0.1751 \\
{[-2.66]^{* * *}}\end{array}$ & $\begin{array}{c}-0.1826 \\
{[-2.77]^{* * *}}\end{array}$ & & $\begin{array}{c}-0.1816 \\
{[-2.28]^{* *}}\end{array}$ & & $\begin{array}{l}0.0836 \\
{[0.86]}\end{array}$ & & $\begin{array}{c}-0.0003 \\
{[-0.00]}\end{array}$ \\
\hline Home region $\mathrm{CN}$ & & $\begin{array}{c}-0.2925 \\
{[-2.09]^{* *}}\end{array}$ & $\begin{array}{c}-0.2895 \\
{[-2.07]^{* *}}\end{array}$ & & $\begin{array}{c}-0.2885 \\
{[-1.96]^{* *}}\end{array}$ & & $\begin{array}{c}-0.0733 \\
{[-0.47]}\end{array}$ & & $\begin{array}{c}-0.0774 \\
{[-0.50]}\end{array}$ \\
\hline Home region CA & & $\begin{array}{c}-0.3344 \\
{[-3.01]^{* * *}}\end{array}$ & $\begin{array}{c}-0.3418 \\
{[-3.08]^{* * *}}\end{array}$ & & $\begin{array}{c}-0.3416 \\
{[-3.07]^{* * *}}\end{array}$ & & $\begin{array}{c}-0.3061 \\
{[-2.73]^{* * *}}\end{array}$ & & $\begin{array}{c}-0.2667 \\
{[-2.34]^{* *}}\end{array}$ \\
\hline Incumbent suppliers & & & & $\begin{array}{c}0.1408 \\
{[2.24]^{* *}}\end{array}$ & $\begin{array}{l}0.0019 \\
{[0.02]}\end{array}$ & & $\begin{array}{r}-0.0325 \\
{[-0.37]}\end{array}$ & & $\begin{array}{l}-0.093 \\
{[-0.98]}\end{array}$ \\
\hline $\begin{array}{l}\text { Total patent stock } \\
\quad(\log 10)\end{array}$ & & & & & & $\begin{array}{l}0.0116 \\
{[0.28]}\end{array}$ & $\begin{array}{c}-0.2351 \\
{[-3.73]^{* * *}}\end{array}$ & & $\begin{array}{c}-0.2257 \\
{[-3.55]^{* * *}}\end{array}$ \\
\hline $\begin{array}{l}\text { 3GPP SEP stock } \\
(\log 10)\end{array}$ & & & & & & $\begin{array}{l}0.0108 \\
{[0.59]}\end{array}$ & $\begin{array}{c}0.1975 \\
{[5.11]^{* * *}}\end{array}$ & & $\begin{array}{c}0.1732 \\
{[4.20]^{* * *}}\end{array}$ \\
\hline $\begin{array}{l}\text { 3GPP participation } \\
\text { intensity }\end{array}$ & & & & & & & & $\begin{array}{c}0.0026 \\
{[2.45]^{* *}}\end{array}$ & $\begin{array}{l}0.0024 \\
{[1.75]^{*}}\end{array}$ \\
\hline Constant & $\begin{array}{c}-1.1236 \\
{[-46.83]^{* * *}}\end{array}$ & $\begin{array}{c}-1.0191 \\
{[-21.82]^{* * *}}\end{array}$ & $\begin{array}{c}-1.0117 \\
{[-21.63]^{* * *}}\end{array}$ & $\begin{array}{c}-1.2083 \\
{[-58.06]^{* * *}}\end{array}$ & $\begin{array}{c}-1.0127 \\
{[-15.66]^{* * *}}\end{array}$ & $\begin{array}{c}-1.2562 \\
{[-7.54]^{* * *}}\end{array}$ & $\begin{array}{l}-0.2926 \\
{[-1.30]}\end{array}$ & $\begin{array}{c}-1.4287 \\
{[-14.52]^{* * *}}\end{array}$ & $\begin{array}{l}-0.4748 \\
{[-1.90]^{*}}\end{array}$ \\
\hline Observations & 14524 & 14524 & 14524 & 14524 & 14524 & 14524 & 14524 & 14524 & 14524 \\
\hline
\end{tabular}

Logistic regression, dependent variable is dummy whether a claimed essential patent is applied for in the 7-day pre-meeting period or not. Values in brackets are z-values. Significance levels: ${ }^{*} p<0.1, * * p<0.05, * * *<<0.01$. Note: (a): For all the home region dummies, the baseline value is 'home base in Europe'.

In Model 4, we considered the effect of being an incumbent supplier. It is a positive, significant effect: the firms that dominated the GSM market (including Nokia, Ericsson, Alcatel, and Siemens) show this strategic patenting behavior more than other firms. They are arguably vested in the standardization game. Combining this incumbent supplier variable with earlier data (Model 5), we again see an expected interdependence, as most of these incumbent firms are in fact European. ${ }^{20}$

The patent stock results are interesting, because although these two variables do not seem to do much by themselves (Model 6), their significance becomes evident when they are controlled for countries as well (Model 7). Companies with large overall patent portfolios show less of this strategic behavior, whereas companies with large portfolios specific to the standards we investigated, show more of it. Finally, the intensity of participation in 3GPP meetings has a positive effect on this strategic behavior, which remains stable after adding all other variables.

To summarize, a strategy of applying for patents in the seven days preceding a standardization meeting is employed (1) mainly by vertically integrated firms (firms based in the USA, which are mostly upstream firms, therefore employ it less often), (2) by the

\footnotetext{
${ }^{20}$ Note that this effect is somewhat harder to see in the regression results, as Europe is the baseline value for the home region dummies.
} 
incumbent champions of the previous technology standard (and therefore mainly by firms in Europe, where these champions are located), (3) by smaller companies that nevertheless have large SEP portfolios for the standard (e.g., very dedicated companies), and finally, and not surprisingly, (4) by companies that very actively participate in 3GPP meetings.

\section{Conclusions and discussion}

The main finding of this study is that firms that participate in standard-setting organizations (SSOs) employ strategies to drive low-merit technologies into standards in order to create large portfolios of essential patents. More specifically, we found that:

(1) In the seven days preceding a standardization meeting, there was a large peak in the filing or provisional filing of patents that eventually became essential. This effect can be mainly attributed to filings of patents whose inventors are also meeting participants. Non-participants show a peak, albeit a smaller one, during the standardization meeting.

(2) Patents applied for in the seven-day period preceding a standardization meeting have an increased likelihood of becoming essential patents, an effect that remains stable after controlling for other possible explanations. In contrast, patents applied for during a standardization meeting do not have an increased likelihood of becoming essential patents.

(3) Essential patents applied for by meeting participants in the seven-day period before the meeting, have a significantly lower citation score than other essential patents. The same is true for essential patents filed during a standardization meeting.

(4) The strategy of applying for patents in the seven days preceding a standardization meeting is mainly employed by vertically integrated firms, incumbent champions of the previous technology, smaller companies that nevertheless have large SEP portfolios, and companies that very actively participate in 3GPP meetings.

In conclusion, we see strong evidence for what we call the "just-in-time" patenting strategy, in which companies apply for patents with low technical merit just before a standardization meeting, and subsequently send the patents' inventors (or other staff) to the meeting where they negotiate their patents into the standard. Our tests show that the timing effect we observe is not merely a deadline effect. We also see evidence for an "on-the-spot" patenting strategy: 
during standardization meetings, companies apply for low-merit patents that are based on information provided by others, or are the result of recombining/reusing the inventions of others. This, however, is a weaker mechanism, and particularly the bargaining of the technology into the standard is less effective.

Our findings have a number of implications. Firstly, if one holds the belief that standards should cover patented technology only if that technology actually brings technical merit to the standard, our observed just-in-time patenting behavior is a cause for concern. The inclusion of such patents may result in a range of effects that are relevant for policymakers, competition authorities, standards implementers, and end users alike. Their inclusion may result in higher prices (when the rents are passed on to end users) and higher barriers to entry for implementers who do not own essential patents themselves, and negatively affect the level of competition in the market. Secondly, their inclusion may unnecessarily complicate the standard and slow down the development process. Thirdly, a wider proliferation of essential patents can also increase the risk of patent holdup: the situation in which once the patent is included in the standard, and implementers are locked in, the patent holder charges a higher licensing fee than would have been possible before the technology was made part of the standard (e.g., ex ante). In such a situation, the patent holder not only charges rents for the technical merit of the patent, but also appropriates for itself the (high) switching costs of the implementers. Patent hold-up can overcompensate patentees, increase prices to consumers (who lose the benefits of competition among technologies), and deter innovation by manufacturers facing the risk of hold-up (FTC, 2011). In addition, given the high societal importance of open standards, we believe these implications are relevant for policymakers and competition/antitrust authorities.

On the basis of these implications, SSOs could be recommended to critically review the patent inclusion process, and reconsider whether just-in-time patenting strategies drive an unnecessarily high number of low-merit patents into their standard. Although we believe that the public at large, SSOs, and the members of SSOs would benefit, at least in the longer term, from a more critical approach to the inclusion of patented technology, we realize that in the short term, many members of SSOs may well be resistant to such changes. A study into how many essential patents do not meet the current EPO bar for novelty (see below) could help to inform both the management of and participants in SSOs about the magnitude of the issue. If an SSO were to curtail the use of low merit patents in standards, one possible approach would be to introduce a more explicit and deliberate choice process for technology inclusion. Whenever patented technologies are proposed, the chairman of the technical committee could ask the committee to take stock of the alternative approaches that would also meet the design 
criteria. Here, the practice of the Internet Engineering Task Force (IETF) may serve as an example: it selects patented technologies only when no unpatented alternatives are available. Even though the IETF's policy may not be directly transposable to other SSOs, because of differences in technology field, patenting strategies, and firm culture, there may well be lessons to learn from the IETF's critical approach. Considering the issue of technology inclusion would fit well with the current activities of SSOs, which are discussing and improving their IPR strategies to find an appropriate balance between right holders and implementers. For instance, in February 2015, the IEEE decided to update its IPR policy after it received a positive assessment of its proposed new policy from the US Department of Justice (IEEE, 2015 and DoJ, 2015). Other SSOs, such as ETSI and ITU, are also discussing clarifications of and updates to their policies.

As argued above, some forms of just-in-time patenting may be possible because when patent offices examine patent applications, they generally do not consider information or documents from the standards-drafting process as prior art. There is an interesting development occurring at the European Patent Office (EPO), challenging this practice. ${ }^{21}$ EPO appeal Case T 202/97 considered a situation in which a party employing the EPO opposition procedure cited preliminary documents and minutes of the meeting of a standard-developing working group (in this case, ISO/TC22/SC3/WG9). In this appeal case, the EPO Technical Board of Appeal came to the conclusion that a proposal sent to the members of an SSO working group in preparation for their meeting, does not usually entail an obligation to maintain confidentiality, and is therefore to be regarded as being available to the public. As such, EPO acknowledged that information shared in the standards-setting context is part of the prior art. A further appeal case, T0050/02, strengthened this view. Taking this one step further, in 2009 EPO signed a memorandum of understanding with several SSOs, in which it states that it will ensure that they have good access to such documentation so that they may examine patent applications (Goudelis, 2012).

Our empirical study was based on USPTO patents (mainly because just-in-time patents use the provisional application procedure offered by the USPTO), but the policy change at the EPO offers interesting opportunities for a follow-up study to determine to what degree justin-time patents stem from patent applications whose content was shared in the standardization setting before the patent application was submitted, either by the applicant or by another party ("stealing"). Such a study could investigate non-patent literature citations in these applications, and the degree to which they resulted in the rejection or granting of the

\footnotetext{
${ }^{21}$ This section is based on Willingmyre (2012).
} 
application. If such a study were to confirm that this is a significant share of patents in the relevant technology fields (or a considerable share of patents disclosed as essential to a given standard), there are two possible ways to curtail such practices. The first is for the world's major patent offices (e.g., the IP5, composed of North America's USPTO, Japan's JPO, South Korea's KIPO, China's SIPO, and Europe's EPO) to adopt a policy similar to that of the EPO, and utilize a common, standards-related documentation. Until such a time as the other major patent offices have adopted such policies, companies are likely to continue their practices. In fact, the EPO has set this as one of its goals (Goudelis, 2012). However, we learned from interviews that this is unlikely to happen in the near future: The USPTO does not seem to have any plans to follow the EPO's lead. In addition, there may be other complications because of the USPTO grace period provision, which allows patent applications to be filed up to 12 months following an inventor's public disclosure of the invention. The second way to curtail just-in-time practices is for SSOs to make public all working group documents (submitted proposals, minutes of meetings, etc.), for instance, by publishing them in a way that makes them regular prior art. This would clearly solve the problem, although it could come at the expense of the willingness of firms to contribute to standards.

As a final point, we would like to state that our study has some limitations. Firstly, our observations are based on only one standardization effort. Although the W-CDMA/LTE standardization effort we studied is an economically very significant one, its findings are not necessarily generalizable to other standard-setting efforts. Across SSOs, and across technology areas in a broader sense, there may be differences in SSOs and meeting rules, and in culture and strategic conduct. Concurrently, we learned from participants at other SSOs that just-in-time strategies are also common in organizations other than ETSI/3GPP. Ideally, this study would be replicated in one of these other organizations, such as the IEEE or ITU. However, doing so is problematic, as these bodies have policies that allow for "blanket declarations," in which companies can declare that they believe they own essential IPR but do not have to identify that IPR. This results in an incomplete dataset of claimed essential IPR. Because a firm's decision to use blanket declarations might not be a random decision (Bekkers and Martinelli, 2013), this would create a serious risk of bias. Such a bias limits our ability to reproduce this study for other technological standards.

A second limitation of our study is that our observation of standard-essential patents was based on disclosures by the patent owners, and thus might have been prone to both overdisclosure (companies falsely declaring patents as SEPs) and under-disclosure (companies failing to declare SEPs). Databases of disclosed patents may also have some other forms of 
bias, such as those discussed in Bekkers and Updegrove (2012). ${ }^{22}$ While we are aware of such problems, there are no real alternatives for a study like this. The ultimate test of essentiality namely a "claim chart" that compares each claim in the patent with the relevant clauses in the standard in question - is a very specialized and expensive exercise, especially if performed for a large set of patents. However, regardless of these limitations, we believe that both SSOs and other stakeholders would benefit from thinking critically about their processes of creating standards and how these are influenced by IPR strategies.

\section{Acknowledgements}

We wish to thank Dr. Michel Goudelis of the European Patent Office for discussing his organization's policy on prior art and standardization. We are thankful for valuable feedback on earlier versions of this paper from Tim Simcoe, Koen Frenken, Arianna Martinelli, and Alessandro Nuvolari, as well as from participants in the 5th ZEW/MaCCI conference, the EMAEE 2013 conference, the 35th DRUID Conference 2013, the IEEE SIIT13 conference, and the 3rd ICTCM conference. We also wish to thank two anonymous reviewers of this paper for their constructive comments.

\section{References}

Aggarwal, N., Dai, Q., Walden, E. A., 2011. The more, the merrier? How the number of partners in a standard-setting initiative affects shareholder's risk and return. MIS Quarterly (35) 2, 445-462.

Baron, J., Ménière, Y., \& Pohlmann, T., 2014. Standards, consortia, and innovation. International Journal of Industrial Organization 36, 22-35.

Bekkers, R. and Martinelli, A., 2013. Covering it up? Determinants of blanket declarations of essential patents in standard-setting organizations. Proceedings of the 8th European Meeting on Applied Evolutionary Economics (EMAEE), 10-12 June 2013, Sophia-Antipolis, France. Retrieved May 15, 2014 from http://ofce-skema.org/wpcontent/uploads/2013/06/martinelli.pdf.

Bekkers, R., \& Updegrove, A., 2012. A study of IPR policies and practices of a representative group of Standards Setting Organizations worldwide. Washington, DC: National Academies of Science. Retrieved May 15, 2014 from http://sites.nationalacademies.org/xpedio/groups/pgasite/documents/webpage/pga 072197.pd f.

\footnotetext{
${ }^{22}$ We would like to note that especially for Japanese firms, our data might have some additional limitations: 3GPP allows its participants to disclose their essential IPR to any of the 3GPP partners, not only ETSI. While the ETSI database is by any standards the most complete one, a quick analysis of the IPR databases of these other partners revealed that some Japanese companies in particular preferred notification to another partner over notification to ETSI.
} 
Bekkers, R., Birkman, L., Canoy, M., de Bas, P., Lemstra, W., Martinelli, A., \& Ménière, Y., 2014. Patents and Standards: A modern framework for IPR-based standardization. A study prepared for the European Commission Directorate-General for Enterprise and Industry. Brussels: European Commission. doi:10.2769/90861.

Bekkers, R., Bongard, R., \& Nuvolari, A., 2011. An empirical study on the determinants of essential patent claims in compatibility standards. Research Policy 40, 1001-1015.

Bekkers, R., Catalini, C., Martinelli, A., \& Simcoe, T., 2012. Intellectual property disclosure in standards development. NBER conference on Standards, Patents \& Innovation, Tucson (AZ), January 20 and 21, 2012. Retrieved May 15, 2014 from http://users.nber.org/ confer/2012/IPKE/Bekkers.pdf.

Berger, F., Blind, K., \& Thumm, N., 2012. Filing behaviour regarding essential patents in industry standards. Research Policy 41, 216-225.

Besen, S. M., \& Levinson, R. J., 2012. Introduction to the special issue on the use and abuse of voluntary standard-setting processes in a post-RAMBUS world: Law, economics, and competition policy. Antitrust Journal 75 (1), 1-16.

Bessen, J., 2004. Holdup and licensing of cumulative innovations with private information, Economics Letters 82 (3), 321-326.

Blind, K., Bekkers, R., Dietrich, Y., Iversen, E., Köhler, F., Müller, B. et al. 2011. Study on the Interplay between Standards and Intellectual Property Rights (IPRs). Final Report. Study commissioned by the European Commission Tender No ENTR/09/015 (OJEU S136 of 18/07/2009). Brussels: European Commission. Retrieved May 15, 2014 http://ec.europa.eu/enterprise/policies/european-standards/standardisation-policy/policyactivities/intellectual-property-rights/index en.htm.

Buehler, B., Koltay, G., Boutin, X. \& Motta, M., 2014. Recent Developments at DG Competition: 2013-2014. Review of Industrial Organization 45 (4), 399-415.

Cargill, C.F., 1989. Information Technology Standardization: Theory, Process and Organizations. Digital Press, Bedford, Massachusetts.

Carpenter, M., Narin, F., Woolf, P., 1981. Citation rates to technologically important patents. World Patent Information 3 (4), 160-163.

Chiao, B., Lerner, J., \& Tirole, J., 2007. The rules of standard-setting organizations: an empirical analysis. RAND Journal of Economics 38 (4), 905-930.

Delcamp, H., \& Leiponen, A., 2014. Innovating standards through informal consortia: The case of wireless telecommunications. International Journal of Industrial Organization 36, 3647.

DOJ, 2015. Press Release of 2 February 2015: "Department of Justice will not challenge standards-setting organization's proposal to update patent policy".

Dokko, G., \& Rosenkopf, L., 2010. Social capital for hire? Mobility of technical professionals and firm influence in wireless standards committees. Organization Science 21 (3), 677-695.

Farrell, J., Hayes, J., Shapiro, C., \& Sullivan, T., 2007. Standard setting, patents, and hold-up. Antitrust Law Journal 74 (3), 603-670.

Fischer, T., Henkel, J., 2012. Patent trolls on markets for technology - An empirical analysis of NPEs' patent acquisitions, Research Policy 41, 1519-1533.

FTC, 2011. The evolving IP marketplace: Aligning patent notice and remedies with competition. Washington D.C.: Federal Trade Commission. 
Gambardella, A., Harhoff, D., \& Verspagen, B., 2008. The value of European patents. European Management Review 5 (2), 69-84.

Gandal, N.; Gantman, N.; Genesove, D., 2007. Intellectual property and standardization committee participation in the U.S. modem industry. In: Greenstein, S.; Stango, V. (Eds., 2007): Standards and Public Policy. Cambridge University Press.

Ganglmair, B., \& Tarantino, E., 2014. Conversation with secrets. The RAND Journal of Economics 45 (2), 273-302.

Geradin, D., Layne-Farrar, A., \& Padilla, A. J., 2008. The complements problem within standard setting: Assessing the evidence on royalty stacking. Boston University Journal of Science \& Technology 14 (2), 144-167.

Goodman, D. J., \& Myers, R. A., 2005. 3G Cellular standards and patents. Proceedings from 2005 IEEE Wireless Communications and Networking Conference.

Goudelis, M, 2012. EPO cooperation with standards developing organisations. Presentation at the National Academies of Science, October 3-4, 2012. Retrieved May 15, 2014 from http://sites.nationalacademies.org/cs/groups/pgasite/documents/webpage/pga 072712.pdf.

IEEE, 2015. Press Release of 8 February 2015: "IEEE Statement Regarding Updating of its Standards-Related Patent Policy".

ITU, 2014. Understanding patents, competition \& standardization in an interconnected world. Geneva: International Telecommunication Union (ITU). Retrieved May 15, 2014 from http://www.itu.int/en/ITU-T/Documents/Manual Patents Final E.pdf.

Jaffe, A. B., \& Trajtenberg, M. (Eds.), 2002. Citations \& Innovations: A Window on the Knowledge Economy. MIT Press.

Kang, B., \& Motohashi, K., 2015. Essential intellectual property rights and inventors' involvement in standardization, Research Policy 44 (2), 483-492.

Karki, M. M. S., 1997. Patent citation analysis: A policy analysis tool. World Patent Information 19 (4), 269-272.

Kobayashi, B. H., \& Wright, J. D., 2010. Intellectual property and standard setting. In ABA Handbook on the Antitrust Aspects of Standards Setting. American Bar Association.

Layne-Farrar, A., 2011. Innovative or indefensible? An empirical assessment of patenting within standard setting. International Journal of IT Standards and Standardization Research $9(2), 1-18$.

Leiponen, A. E., 2008. Competing through cooperation: The organization of standard setting in wireless telecommunications. Management Science 54 (11), 1904-1919.

Lemley, M. A., \& Shapiro, C., 2007. Patent holdup and royalty stacking. Texas Law Review 85, 1991-2049.

Lemley, M. A., 2002. Intellectual property rights and standard-setting organizations. California Law Review 90 (6), 1889-1980.

Lerner, J., \& Tirole, J., 2014. Better route to tech standards, Science 343, 972-973.

Lerner, J., \& Tirole, J., 2015. Standard-Essential Patents. Journal of Political Economy $123(3), 547-586$

Lindsay, M. A., 2012. Safeguarding the standard: Standards organizations, patent hold-up, and other forms of capture. Antitrust Journal 75 (1), 17-58. 
Mallinson, K., 2011. Valuing IP in smartphones and LTE. WiseHarbor. Retrieved May 15, 2014 from

https://sites.google.com/site/ipfinanceweblog/wiseharbor/WiseHarborvaluingIP7Nov11pdf.pd f?attredirects $=0 \& d=1$.

Martin, D. L., \& De Meyer, C., 2006. Patent counting, a misleading index of patent value: A critique of Goodman \& Myers and its uses. Retrieved May 15, 2014 from at SSRN:

http://ssrn.com/abstract $=949439$.

Maskus, K., \& Merrill, S. A. (Eds.), 2013. Patent challenges for standard-setting in the global economy: Lessons from the ICT industry. Committee on Intellectual Property Management in Standard-Setting Processes Board on Science, Technology, and Economic Policy, Policy and Global Affairs. National Research Council of the National Academies. Washington, D.C.: The National Academies Press.

Omachi, M., 2004. Emergence of essential patents in technical standards: Implications of the continuation and divisional application systems and the written description requirement. Working Paper WP 05-02, Institute of Innovation Research (IIR), Hitotsubashi University Repository.

Pohlmann, T. Neuhäusler, P. \& Blind, K., 2015. Standard essential patents to boost financial returns. R\&D Management, published online: 6 May 2015. DOI: 10.1111/radm.12137.

Rysman, M., \& Simcoe, T., 2008. Patents and the performance of voluntary standard-setting organizations. Management Science 54 (11), 1920-1934.

Shapiro, C., 2001. Navigating the patent thicket: Cross licenses, patent pools, and standard setting. In A. Jaffe, J. Lerner, \& S. Stern (Eds.), Innovation Policy and the Economy (Vol. 1). National Bureau of Economic Research / MIT Press.

Sidak, J. G., 2009. Patent holdup and oligopsonistic collusion in standard-setting organizations. Journal of Competition Law and Economics 5 (1), 123.

Trajtenberg, M., 1990. A penny for your quotes: Patent citations and the value of innovations. RAND Journal of Economics 21, 172-187.

Van Zeebroeck, N., 2011. The puzzle of patent value indicators. Economics of Innovation and New Technology 20 (1), 33-62.

Willingmyre, G. T., 2012. Cooperation between patent offices and standards developing organizations. Washington, DC: National Academies of Science. Retrieved May 15, 2014 from http://sites.nationalacademies.org/xpedio/groups/pgasite/documents/webpage/pga 072350.pd f. 


\section{Appendix A: Overview of variables for regression in Section 4.4}

\begin{tabular}{|c|c|c|}
\hline Business model & Upstream business model & $\begin{array}{l}\text { Dummy; takes value } 1 \text { when the organization is one of the following: } \\
\text { (i) pure upstream knowledge developer or patent holding company } \\
\text { (excl. universities); (ii) university / public research institute / state; } \\
\text { (iii) component supplier (incl. semiconductors); (iv) software and } \\
\text { software-based services. }\end{array}$ \\
\hline \multirow[t]{5}{*}{ Home region } & US & $\begin{array}{l}\text { Dummy; takes value } 1 \text { if home base is the United States. Note: for all the } \\
\text { home region dummies, the baseline value is home base in Europe. }\end{array}$ \\
\hline & $\mathrm{KR}$ & Dummy; takes value 1 when home base is South Korea. \\
\hline & $J P$ & Dummy; takes value 1 when home base is Japan. \\
\hline & $\mathrm{CN}$ & Dummy; takes value 1 when home base is China. \\
\hline & CA & Dummy; takes value 1 when home base is Canada. \\
\hline Incumbent suppliers & Incumbent suppliers & $\begin{array}{l}\text { Dummy; takes value } 1 \text { when company is full ETSI "manufacturer" } \\
\text { member and had voting power of } 18 \text { or more in ETSI per January } 1998- \\
\text { this is the case for } 6 \text { out of the total of } 31 \text { ETSI "manufacturer" member } \\
\text { companies. (Note that not all companies in our overall dataset are or } \\
\text { were ETSI members at that time.) }\end{array}$ \\
\hline \multirow[t]{2}{*}{ Patent stock } & Total patent stock $(\log 10)$ & $\begin{array}{l}\text { The log10 of the total number of patent families owned by that firm, as } \\
\text { determined by the Thomson's Derwent Innovation Index (DII). }\end{array}$ \\
\hline & 3GPP SEP stock (log10) & $\begin{array}{l}\text { The log10 of the total number of USPTO and EPO patents declared } \\
\text { essential to the 3GPP W-CDMA and LTE standards, based on the OEIDD } \\
\text { database. }\end{array}$ \\
\hline $\begin{array}{l}\text { Intensity of } \\
\text { participation }\end{array}$ & $\begin{array}{l}\text { 3GPP participation } \\
\text { intensity }\end{array}$ & $\begin{array}{l}\text { Percentage of the 3GPP RAN-1 meetings actually attended by } \\
\text { representatives of the firm. }\end{array}$ \\
\hline
\end{tabular}

\section{Appendix B: Overview of correlations between variables in regression of Section 4.4}

\begin{tabular}{|c|c|c|c|c|c|c|c|c|c|c|}
\hline Upstream business model & 1 & & & & & & & & & \\
\hline US & $-0.2894 * * *$ & 1 & & & & & & & & \\
\hline KR & $-0.3037 * * *$ & $-0.2226 * * *$ & 1 & & & & & & & \\
\hline$J P$ & $-0.3444 * * *$ & $-0.2027 * * *$ & $-0.2378 * * *$ & 1 & & & & & & \\
\hline $\mathrm{CN}$ & $-0.0982 * * *$ & $-0.0678 * * *$ & $-0.0796 * * *$ & $-0.0725 * * *$ & 1 & & & & & \\
\hline CA & $-0.1542 * * *$ & $-0.0907 * * *$ & $-0.1065 * * *$ & $-0.0969 * * *$ & $-0.0324 * *$ & 1 & & & & \\
\hline Incumbent suppliers & $-0.2459 * * *$ & $0.6148 * * *$ & $-0.1727 * * *$ & $-0.1573 * * *$ & $-0.0526 * * *$ & $0.2252 * * *$ & 1 & & & \\
\hline Total patent stock $(\log 10)$ & $-0.441 * * *$ & $-0.2871 * * *$ & $0.5365 * * *$ & $0.2599 * * *$ & $0.089 * * *$ & $-0.134 * * *$ & $-0.1137 * * *$ & 1 & & \\
\hline 3GPP SEP stock (log10) & $0.5341 * * *$ & $-0.2779 * * *$ & $0.3058 * * *$ & $-0.6267 * * *$ & $-0.167 * * *$ & $-0.1756 * * *$ & $-0.1571 * * *$ & $0.0451 * * *$ & 1 & \\
\hline 3GPP participation intensity & $0.1641 * * *$ & $-0.2093 * * *$ & $0.1521 * * *$ & $0.0429 * * *$ & $-0.2254 * * *$ & $-0.3122 * * *$ & $0.0244 *$ & $0.1772 * * *$ & $0.4195^{* * *}$ & 1 \\
\hline
\end{tabular}




\section{List of abbreviations}

2G: Second Generation (of cellular wireless technologies)

3G: Third Generation (of cellular wireless technologies)

3GPP: Third Generation Partnership Project

4G: Fourth Generation (of cellular wireless technologies)

ARIB: Association of Radio Industries and Businesses (Japan)

CDMA: Code Division Multiple Access

EPO: European Patent Office

ETSI: European Telecommunications Standards Institute

FRAND: Fair, Reasonable And Non-Discriminatory

FTC: Federal Trade Commission (US)

GSA: Global Mobile Suppliers Association

GSM: Global System for Mobile Communications, originally Groupe Spécial Mobile

HSPA: High Speed Packet Access

IEEE: Institute of Electrical and Electronics Engineers

IETF: Internet Engineering Task Force

IPC: International Patent Classification

IPR: Intellectual Property Right

ISO: International Organization for Standardization

IT: information technology

ITU: International Telecommunication Union

KIPO Korean Intellectual Property Office

LAN: Local Area Network

LTE: Long Term Evolution

MPEG: Moving Picture Experts Group

NBER: National Bureau for Economic Research (US)

NPE: Non-Practicing Entity

OECD: Organisation for Economic Co-operation and Development

OEIDD: Open Essential IPR Disclosure Database

PATSTAT: EPO Worldwide Patent Statistical Database

RAN1: Radio Access Network 1 (a 3GPP working group)

SEP: Standard-Essential Patent

SIPO: State Intellectual Property Office (the patent office of the People's Republic of China)

SSO: Standard Setting Organization

TTA: Telecommunications Technology Association (Korea)

UMTS: Universal Mobile Telecommunications System

USPTO: United States Patent and Trademark Office

W-CDMA: Wideband Code Division Multiple Access 